\title{
Influence of Perceived Corporate Social Responsibility on Brand Image, Satisfaction and Trust
}

\section{Humyra Dawood*}

\begin{abstract}
The purpose of this research is to analyse the influence of consumers' perception of Corporate Social Responsibility (CSR) practices on a brand's image, satisfaction and trust in Pakistan. While the strategic importance of CSR, as a corporate marketing tool, is fairly established in the developed world, the concept is still finding its ground in developing countries. This study focuses on the consumers of the apparel industry of Pakistan, and has used the Structural Equation Modelling (SEM) to test the model. The findings show that the perceived CSR affects brand image in a positive manner, but has no impact on consumer satisfaction and trust directly. Brand image, however, has a favourable effect on both satisfaction and trust, and completely mediates the relationship between perceived CSR, and satisfaction and trust. This study provides insights to apparel manufacturers to formulate corporate marketing strategies that aim at enhancing their brand image through CSR activities.
\end{abstract}

Keywords: Corporate social responsibility, brand image, trust, satisfaction, structural equation modelling.

JEL Classification: M10, M14, M31.

\section{Introduction}

Corporate Social Responsibility (CSR) comprises of discretionary actions by organizations due to their moral and ethical obligations towards their various stakeholders. The domain of CSR assumed importance from the 1950's, when Bowen (1953) asked what responsibilities were businesses expected to assume towards society. Davis (1960) further advocated CSR, and defined it as those actions that were taken by businesses for reasons not directly related to the firm's economic and technical interests. A review by Murphy (1978) characterized the 60's and 70's as periods of 'awareness' and 'issues' of CSR, where businesses recognized their responsibility towards social affairs and environmental issues, and increased their

\footnotetext{
*Visiting Faculty, Lahore School of Economics, Lahore, Pakistan.
} 
charitable donations to various causes. Furthermore, corporations were driven towards social responsibility without the expectation of any impact on the financial performance of their business (Lee, 2008). According to Carroll (1979), the societal expectation of CSR, from corporations, included their consciousness towards their economic, legal, ethical and philanthropic responsibility. CSR activities have been posited to include corporate philanthropy, minority support programs, cause-related marketing, socially responsible employment and manufacturing practices, as well as community organizations' goals advancement. At the end of the 1990's, CSR was advocated by all members of the society, including governments, corporations, academics and consumers alike.

In the more recent times, CSR has become a universal notion, and is used strategically by organizations to enhance business profitability. Porter and Kramer (2002) urged businesses to use philanthropy in a manner that was strategic in nature, in order to open up new business avenues and opportunities in the long-run. They advocated creating 'shared value' for the company, as well as the society, which would be a novel approach towards achieving economic success. Now, companies are increasingly focusing their efforts towards CSR activities with the aim to address the concerns of different stakeholders, such as consumers, employees, governments, shareholders, etc., so that these actions can result in profitable responses from the concerned stakeholders (Sen \& Bhattacharya, 2001). It is believed that organizations should extend their marketing outlook, so as to include other stakeholders, besides consumers, and integrate their marketing activities with the CSR initiatives that they wish to undertake and represent (Maignan \& Ferrell, 2004). CSR can serve as a tool for companies to differentiate their product from competitors, and strengthen their brand identities. Effective corporate marketing strategies cannot be formulated, if the key role of CSR is ignored (Hildebrand, Sen \& Bhattacharya, 2011).

Most of the previous discussions on CSR have been focused towards and in the developed economies of the world, but limited studies have been carried out in the developing economies such as Pakistan. In the developed world, consumers are conscious of CSR responsibilities, and consider this aspect as a criteria when making their purchase decisions. Attitude and loyalty towards the company and brand are positively influenced by CSR activities undertaken by the business (Arli \& Lasmono, 2010). However, it must be noted that CSR activities and initiatives are still in their nascent stages in Pakistan. It is largely due to the disinterest of the government and the relevant governing bodies in enforcing regulations, 
low pressure by media and corporate shareholding that is concentrated in a few hands. Social responsibility is restricted to corporate philanthropy, and minimal importance is given to the responsibilities towards other stakeholders, such as the consumers (Ahmad, 2006).

This research has been undertaken for the purpose of investigating whether different levels of CSR, initiated by the apparel manufacturers of Pakistan, influence the brand image, and consumers' perceptions of satisfaction and trust. Consumers have become increasingly aware of CSR in the last decade (Becker-Olsen, Cudmore \& Hill, 2006), and it is now essential to see how this awareness will influence consumer behaviour in relation to the apparel industry. The apparel industry forms a significant part of the country's economy, and no study in Pakistan has yet analysed the perceptions and beliefs of consumers with regard to this industry. This study measures how consumers of the apparel industry evaluate CSR activities of the apparel industry, in relation to philanthropy, environmental footprint, attitude towards employees and consumer rights. It also examines the impact of CSR initiatives on brand image, trust and consumer satisfaction. Marketing executives and business managers can use the results of this research to formulate strategies that utilize CSR as a marketing tool.

Keeping this in mind, the research questions to be answered by this study aim to clarify whether perceived CSR has an impact on brand image for consumers? How does brand image affect consumer satisfaction and trust? Does perceived CSR also influence consumer satisfaction and trust? Finally, does a brand's image mediate the relationship between perceived CSR, satisfaction and trust? The rest of the paper is structured so as to extract, and interpret the results in a systematic manner. First, the literature is reviewed and the research hypotheses are developed. Then, the conceptual model that is proposed is validated through the Confirmatory Factor Analysis (CFA), and the Structural Equation Modelling (SEM). The last sections of the paper presents the findings of the analysis, discusses the results and outlines the limitations.

\section{Literature Review and Hypotheses Development}

\subsection{Corporate Social Responsibility}

The literature is abound with various definitions of CSR, but there is no consensus on how it should be ultimately defined. The most wellknown typology of CSR was given by Carroll (1979), where he classified 
social responsibility into four categories; economic, legal, ethical and philanthropic. He suggested that for businesses, economic responsibility assumed the highest priority. This was followed by legal, ethical and then philanthropic responsibilities. Economic responsibilities deal with, producing at a profit, what is demanded by consumers. Legal responsibility refers to fulfilling the economic responsibilities within the fair legal framework. Ethical responsibilities are those which require a business to operate in an economically fair and just manner. Philanthropic responsibilities are those activities that a business undertakes in order to improve the overall societal welfare, by attaching itself with a specific cause. A review of the various definitions by Dahlsrud (2006) eventually led to the suggestion of five dimensions of CSR, namely, stakeholder, social, economic, voluntariness and environmental. CSR initiatives have also been postulated to comprise of philanthropy, socially responsible attitude towards employees, safe manufacturing operations, support for minorities, and marketing for social causes (Drumwright, 1994). Thus, CSR can be perceived by consumers in terms of any of these dimensions, and the present study has evaluated the perceived CSR activities in Pakistan as a second-order construct, evaluated in terms of the environment, employees, consumers and philanthropy.

\subsubsection{CSR \& Brand Image}

The idea of "brand picture" was first conceptualized by Levy (1959), when he proposed that items have social and mental qualities and hence, purchasers create enthusiastic associations with the brands. Plummer (1985) said that the brand image formation was initially launched through the social affair of inborn and extraneous traits, advantages, and outcomes that are connected with the brand. A brand's image is fabricated through the communication between the brand, and its stakeholders (Ruão, 2003), and it is actually the purchaser's observation about the brand (Ballantyne, Warren \& Nobbs, 2005). A strong brand image makes products seem more attractive, and can lead the consumers into buying more of what they desire, or what appeals to them (Shamma \& Hassan, 2011). Corporate communication affects the perception of the brand's image, and leads to the consumers associating their minds freely to that particular product. In the fashion industry, the brand image plays a more important role, as compared to that in the other industries (Carrigan \& Attalla, 2001), and even though it can be influenced by a number of marketing activities, CSR is one activity that has a strong impact on brand image (Lion, Macchion, Danese \& Vinelli, 2016). According to BeckerOlsen et al. (2006), CSR initiatives can create a positive brand image in the 
minds of the consumers, and encourages them to actively associate themselves and their loyalties with a particular brand (He \& Li, 2011). Due to this business tactic, the players in the fashion industry have realized that CSR is a vital tool in improving their brand's image and eventually sales (Da Giau et al., 2016). A study by Othman and Hemdi (2013) revealed that there was a positive and significant relationship between CSR activities and a brand's image. Thus, the first research hypothesis can be formulated, based on these revelations and studies.

Hypothesis 1: Perceived CSR has a positive impact on brand image.

\subsubsection{CSR and Trust}

Crosby, Evans and Cowles (1990) defined consumer trust as the belief that a product will behave in a way that it serves the long-term interests of the consumer. Relationships between corporations and consumers can only be maintained in the long run if trust is present. This trust is affected by a shared value system that exists between the company and the consumers, when it comes to important and appropriate behaviours and policies that a company represents (Morgan \& Hunt, 1994). An individual experience a greater level of trust, when s(he) is firmly able to believe in the company's promises regarding their CSR activities and higher ethical standards (Kim, 2019; Park, Kim \& Kwon, 2017). CSR initiatives by corporations communicate their understanding of core business values to the consumers (Turban \& Greening, 1997), and are important in increasing their trust in the company (Aaker, 1996). Injecting and incorporating culturally appropriate ethical principles into the companies' strategic decision-making processes can lead to a higher level of trust of all stakeholders, including consumers (Hosmer, 1994). Moreover, effectively communicating a company's CSR initiatives to consumers can help build trust and this trust can erode if consumers get exposed to negative information about the organization (Bögel, 2019). Thus, the second hypothesis can be built on the above discussion.

Hypothesis 2: Perceived CSR has a positive impact on the consumer's trust.

\subsubsection{CSR and Satisfaction}

Consumer satisfaction is not inherently present in a product, but rather, it comprises of an individual's perceptions of a product's characteristics and how they relate to his/her personality and 
circumstances (Boshoff \& Gray, 2004). Ueltschy, Laroche, Eggert and Bindl (2007) observed that a similar experience with different products can lead to varying levels of satisfaction, for different individuals. The perceived value of a particular product can also lead to higher levels of satisfaction (Mithas, Krishnan \& Fornell, 2005). The literature suggests that CSR activities can effect consumer satisfaction, as consumers are likely to be more satisfied by the products and services offered by firms that are actively practicing the CSR (Luo \& Bhattacharya, 2006). If organizations behave in a socially responsible manner, and engage in CSR activities and initiatives, it will lead to a higher level of satisfaction in the consumers (He \& Li, 2011; Kassinis \& Soteriou, 2015; Walsh \& Bartikowski, 2013). Thus, it can be assumed that the perception of CSR initiatives by corporates can positively affect the consumer satisfaction, and hence, keeping this in mind I can put forward the following research hypothesis.

Hypothesis 3: Perceived CSR has a positive impact on consumer's satisfaction.

\subsection{Brand Image, Trust \& Satisfaction}

Brand image has been defined by Kotler (2001) as "the set of beliefs, ideas, and impressions that a person holds regarding an object". It has also been defined as "a set of perceptions about a brand, as reflected by brand associations in consumer's memory" (Keller, 1993, p 1-22). A strong brand might enhance its consumer's satisfaction, which might compel them to recommend the brand to those within their network of different relationships (Aaker, 1991). Romaniuk and Sharp (2003) noted that when brand attributes are associated with positive images, they produce favourable brand attitudes in consumers, which leads to a higher level of satisfaction with the brand. Also, a strong perception of CSR can enhance the image of the brand, which can have an impact on the consumers' opinion of the organization (Sen \& Bhattacharya, 2001). This leads to the formation of the following hypotheses of this study.

Hypothesis 4: Brand image has a positive impact on Consumer Satisfaction

Hypothesis 4a: Brand image mediates the relationship between perceived CSR and consumer satisfaction.

The perception of a brand in the market has the ability to create optimistic outcomes, and results in increased reciprocity between the brand and the buyer (Creed \& Miles, 1996). When consumers realise that a 
brand has a favourable standing in the minds of other buyers, they will be inclined towards developing a relationship of trust with the particular brand in question and purchase the product. Empirical research also supports the impact of a strong brand image on the consumer's ability to trust (Esch, Langner, Schmitt \& Geus, 2006; Ming, Ismail \& Rasiah, 2011), and thus the fifth hypothesis is put forward.

Hypothesis 5: Brand image has a positive impact on trust.

Hypothesis 5a: Brand image mediates the relationship between perceived CSR and trust.

The above hypotheses leads to the following framework as shown in Figure 1.

Figure 1: Conceptual Model

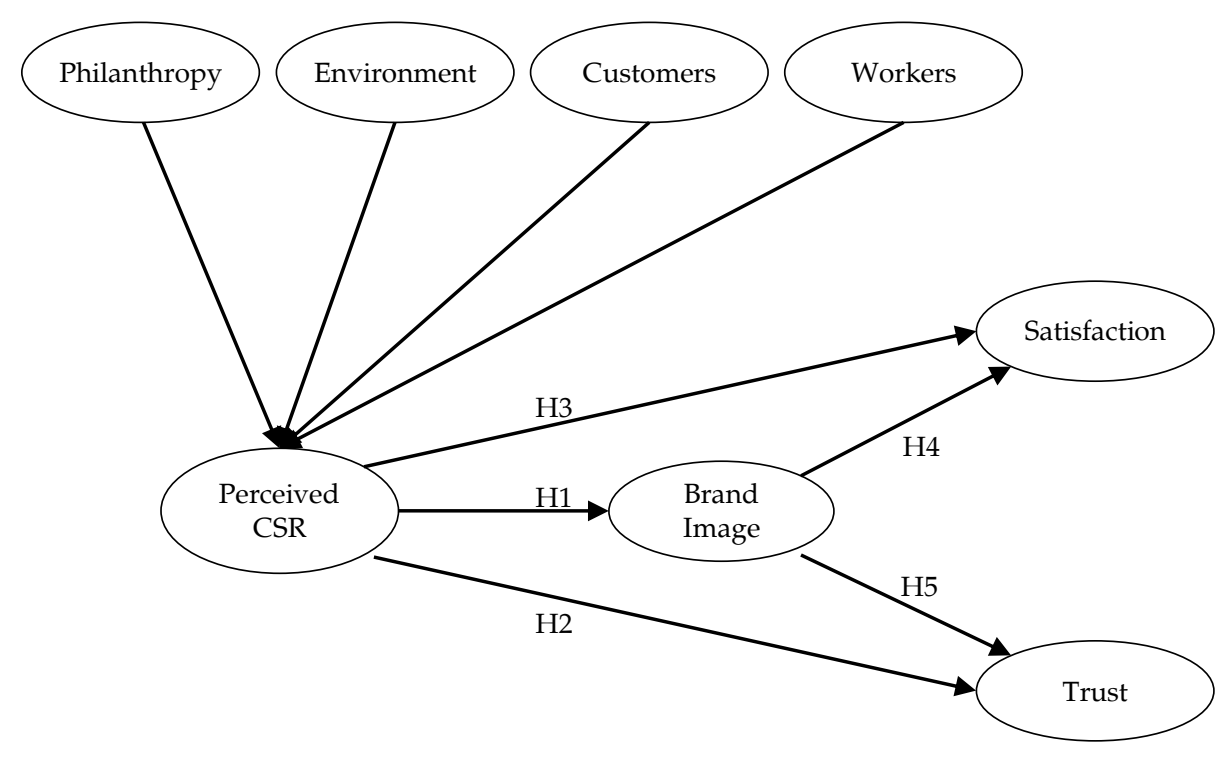

\section{Methodology}

This study falls under the positivist paradigm. A quantitative research design based on cross-sectional survey methodology was used. The research approach is deductive in nature, as the hypotheses have been developed based on existing theory and the research strategy has been designed accordingly to test the constructed hypotheses. 


\subsection{Sample}

The target population for this study consists of the consumers of the apparel industry of Pakistan. The population sample has been selected via stratified random sampling and young people between the ages of 1826 have been targeted for this purpose. Moreover, this study uses primary data, which has been collected through structured questionnaires. It must be noted that the questionnaire administrator was mostly available to answer any questions that the respondents had, and any confusion or ambiguity was cleared at the time of filling the questionnaire. In some cases, the respondents filled the questionnaire in the absence of the administrator and returned these at a later time. 300 respondents in three universities of Lahore were surveyed, out of which 217 respondents returned the questionnaires. 202 questionnaires were usable, as the others either had missing data or were discarded due to extremity bias. All the responses were measured on a 5-point Likert Scale where 1=strongly disagree, $2=$ disagree, $3=$ neutral, $4=$ agree, $5=$ strongly agree.

The first section of the questionnaire contained demographic information about the respondent, which included age, gender, family income and background. The questionnaire had separate sections measuring the different variables used in the study. 18 items were adopted from the study of Swaen and Chumpitaz (2008) to measure CSR, while six items were included to measure the aspect of trust. 14 items were taken from the study conducted by Sonodh, Wahid, Omar, Ismail and Harun (2007), to measure the brand image, while five items were included for the measurement of consumer satisfaction.

\subsection{Measures}

Perceived Corporate Social Responsibility: The only independent variable in this study is CSR. The instrument used to measure this variable was developed by Swaen and Chumpitaz (2008) and contained 18 items.

Brand Image: The mediating variable in this study was Brand Image, which was measured using 14 items that were adopted from Sonodh et al. (2007).

Trust: The first dependent variable is Trust, which was assessed using the instrument developed by Swaen and Chumpitaz (2008), and contained six items. 
Consumer Satisfaction: The second dependent variable that is used in the study is Consumer Satisfaction. This was operationalized by the instrument developed by Sonodh et al. (2007), and included five items.

\section{Analysis of Findings}

\subsection{Descriptive Statistics}

Table 1 reports the demographic characteristics of the sample. $64.4 \%$ of the respondents were females, and $35.6 \%$ were males. Only $23.7 \%$ were married, while $76.2 \%$ were still single. Most of the respondents were well-educated, with 56.4\% of them having a Graduate degree, and 15.8\% with a Master's degree. 9.9\% had acquired Professional degrees, while $17.8 \%$ had other diplomas or qualifications.

Table 1: Demographics.

\begin{tabular}{lcc}
\hline Characteristics & N & Percentage \\
\hline Gender & 72 & \\
Male & 130 & $35.6 \%$ \\
Female & & $64.4 \%$ \\
\hline Education & 114 & \\
Graduate & 32 & $56.4 \%$ \\
Masters & 20 & $15.8 \%$ \\
Professionals & 36 & $9.9 \%$ \\
Other & & $17.8 \%$ \\
\hline Marital Status & 154 & \\
Single & 48 & $76.2 \%$ \\
Married & & $23.7 \%$ \\
\hline
\end{tabular}

\subsection{Measurement Model Assessment - Confirmatory Factor Analysis}

The hypothesized relationships among the constructs in the proposed framework were tested using the 'Structural Equation Modelling' (SEM). SEM is a multivariate analysis technique that is used to address several relations that are present simultaneously in a model (Kerlinger \& Lee, 2000). It is effective when there are structural relationships present in the models with measured variables and latent constructs. SEM requires the analysis of two models: a measurement model and a regression model. The measurement model is analysed using the Confirmatory Factor Analysis (CFA), which tests the reliability and validity of the research instruments, and determines the overall fitness of the measurement model (Bartholomew \& Knott, 1999). 
The CFA was conducted on four latent variables, or constructs, to confirm the factor structure between them, as well as the items used to measure the structure. The results are indicated in Table 2. Brand image, trust and satisfaction are first-order constructs, whereas perceived CSR is a second-order construct measured by perceptions of philanthropy, environment, consumers and workers. Perceived CSR has been represented as a second-order construct due to the existence of theoretical foundations and the correlation between the first-order factors, which indicates that these factors might converge towards a higher-order factor (Swaen \& Chumpitaz, 2008).

Table 2: CFA of Constructs in the Model

\begin{tabular}{|c|c|c|}
\hline & Weights & Alpha \\
\hline $\begin{array}{l}\text { Consumers' perceptions of a company's philanthropic } \\
\text { activities }\end{array}$ & & 0.694 \\
\hline Help developing countries & 0.665 & \\
\hline $\begin{array}{l}\text { Support social and cultural activities (arts, culture, sports) in } \\
\text { the regions where it operates }\end{array}$ & 0.694 & \\
\hline Develop projects in poor countries* & - & \\
\hline Support humanitarian cause(s) & 0.608 & \\
\hline $\begin{array}{l}\text { Consumers' perceptions of a company's environmental } \\
\text { activities }\end{array}$ & & 0.754 \\
\hline Reduce its consumption of natural resources & 0.586 & \\
\hline Make its production process more environmentally friendly & 0.945 & \\
\hline Make its products as ecological as possible* & - & \\
\hline $\begin{array}{l}\text { Consumers' perceptions of a company's customer-related } \\
\text { activities }\end{array}$ & & 0.731 \\
\hline $\begin{array}{l}\text { Look after consumers' rights (in terms of after-sales service, } \\
\text { guarantees, information) }\end{array}$ & 0.674 & \\
\hline Treat customers fairly & 0.782 & \\
\hline $\begin{array}{l}\text { Provide consumers with accurate information about the } \\
\text { products' composition }\end{array}$ & 0.607 & \\
\hline $\begin{array}{l}\text { Consumers' perceptions of a company's worker-related } \\
\text { activities }\end{array}$ & & 0.784 \\
\hline $\begin{array}{l}\text { Treat workers fairly irrespective of gender and ethnic or } \\
\text { religious background }\end{array}$ & 0.612 & \\
\hline Create jobs* & - & \\
\hline Act in accordance with current laws and legislation* & - & \\
\hline Protect employee rights & 0.622 & \\
\hline Help all employees who so desire to receive further training* & - & \\
\hline Guarantee employees' health and safety & 0.715 & \\
\hline $\begin{array}{l}\text { Respect human rights in all countries where the company } \\
\text { operates }\end{array}$ & 0.801 & \\
\hline Not operate in countries where human rights are violated* & - & \\
\hline
\end{tabular}




\begin{tabular}{|c|c|c|}
\hline & Weights & Alpha \\
\hline CSR (second-order construct) & & 0.823 \\
\hline $\begin{array}{l}\text { Consumers' perceptions of company's philanthropic } \\
\text { activities }\end{array}$ & 0.828 & \\
\hline $\begin{array}{l}\text { Consumers' perceptions of company's environmental } \\
\text { activities }\end{array}$ & 0.691 & \\
\hline $\begin{array}{l}\text { Consumers' perceptions of company's customer-related } \\
\text { activities }\end{array}$ & 0.662 & \\
\hline $\begin{array}{l}\text { Consumers' perceptions of company's worker-related } \\
\text { activities }\end{array}$ & 0.746 & \\
\hline Brand Image & & 0.820 \\
\hline Brand $X$ makes me feel good* & - & \\
\hline Brand $X$ makes me feel delighted* & - & \\
\hline Brand $X$ increases my frequency of use ${ }^{*}$ & - & \\
\hline Brand $X$ gives me pleasure & 0.603 & \\
\hline Usage of Brand X prevents me from looking cheap* & - & \\
\hline $\begin{array}{l}\text { Brand X enhances the perceptions that I have a desirable } \\
\text { lifestyle }\end{array}$ & 0.630 & \\
\hline Brand $X$ helps me to better fit into my social group & 0.760 & \\
\hline Brand X helps me feel accepted & 0.694 & \\
\hline Brand $\mathrm{X}$ improves the way I am perceived by others & 0.760 & \\
\hline Brand $\mathrm{X}$ performs as it promises ${ }^{*}$ & - & \\
\hline Brand $X$ can be dependable for use ${ }^{*}$ & - & \\
\hline Brand $\mathrm{X}$ makes a good impression of me on other people* & - & \\
\hline Trust & & 0.759 \\
\hline This company's products give me a sense of security & 0.625 & \\
\hline I trust the quality of this company's products & 0.777 & \\
\hline Buying this company's products is a quality guarantee & 0.741 & \\
\hline This company is interested in its customers & - & \\
\hline This company is forthright in its dealing with consumers* & - & \\
\hline This company is honest with its customers* & - & \\
\hline Satisfaction & & 0.842 \\
\hline I think that I did the right thing when I used this brand* & - & \\
\hline $\begin{array}{l}\text { I believe that using this brand is usually a very satisfying } \\
\text { experience }\end{array}$ & 0.775 & \\
\hline I am very satisfied with my decision to use this brand & 0.832 & \\
\hline My choice to use this brand has been a wise one & 0.715 & \\
\hline This brand does a good job of satisfying my needs & 0.696 & \\
\hline
\end{tabular}

* Items eliminated because their factorial charge was too low.

** Standardized parameters significant to the mlevel of 5\%.

A repeated process was conducted to drop items that had factor loadings of less than 0.5 . As seen in the Table 2, in the final measurement model, several items with factor loadings of less than 0.5 were deleted, and all the final items were loaded highly on one construct (Hair, Anderson, Tatham \& Black, 1995). The internal consistency of the constructs was tested through the Cronbach's alpha value. The survey instrument, i.e. the 
Cronbach's alpha, proved to be reliable, as all the variables achieved alphas that were greater than 0.7 (Nunnally, 1978). To establish the construct validity, both convergent and discriminant validity were analysed. For convergent validity, Fornell and Larcker (1981) suggest that the Average Variance Extracted (AVE) should be more than 0.5, and the construct's reliability should be greater than 0.7 . Table 3 shows that all latent variables fall true to this criteria, except for brand image, which has an AVE of 0.479. However, since the construct was reliable and all final items had factor loadings of greater than 0.5 , it was decided that the variable should be retained. All latent variables in the study exhibited discriminant validity as the average of squared variance (ASV) between the constructs was less than the AVE, and the measures of each construct did not have high correlations with the other constructs (Sekaran, 2000).

The overall fit of the model was assessed by examining multiple indices that included the ratio of the chi square to degrees of freedom, the comparative fit index (CFI), the normed fit index (NFI), and root mean square error of approximation (RMSEA). Several indices were used since the model could be adequate on one index but not on others (Bollen, 1989). As suggested by Hair, Anderson, Tatham and Black (1995), and Byrne (2010), goodness of fit is achieved when the ratio of chi square to the degrees of freedom is between 2 and 5, CFI and NFI > 0.9, and RMSEA < 0.8 . In the final measurement model attained, the ratio of chi square to the degrees of freedom is $1.95, \mathrm{NFI}=0.879, \mathrm{CFI}=0.901$ and $\mathrm{RMSEA}=0.069$. Although the model does not meet the criteria of NFI, we can conclude that overall, the measurement model is deemed to be satisfactory.

Table 3: Convergent Validity, Construct Reliability \& Discriminant Validity

\begin{tabular}{lccc}
\hline Latent Variables & $\begin{array}{c}\text { Average Variance } \\
\text { Extracted (AVE) }\end{array}$ & $\begin{array}{c}\text { Construct } \\
\text { Reliability }\end{array}$ & $\begin{array}{c}\text { Average Shared } \\
\text { Variance (ASV) }\end{array}$ \\
\hline Perceived CSR & 0.539 & 0.823 & 0.257 \\
Brand Image & 0.479 & 0.820 & 0.355 \\
Trust & 0.514 & 0.759 & 0.363 \\
Satisfaction & 0.572 & 0.842 & 0.298 \\
\hline
\end{tabular}

*Measured through Cronbach's Alpha

\subsection{Structural Model Assessment-Hypothesis Testing}

Table 4 presents the estimated standardized coefficients for the structural relationships between perceived CSR, brand image, trust and 
satisfaction. As seen from the table, all coefficients are statistically significant, except for perceived CSR and trust, and perceived CSR and satisfaction.

Table 4: Standardized Regression Weights of Structural Model

\begin{tabular}{lcccc}
\hline Hypothesis & Relationship & Estimate & P-value & Decision \\
\hline HI & Perceived CSR $\rightarrow$ Brand Image & 0.619 & .000 & Accept \\
H2 & Perceived CSR $\rightarrow$ Trust & 0.019 & .859 & Reject \\
H3 & Perceived CSR $\rightarrow$ Satisfaction & 0.167 & .147 & Reject \\
H4 & Brand Image $\rightarrow$ Trust & 0.398 & .000 & Accept \\
H5 & Brand Image $\rightarrow$ Satisfaction & 0.408 & .000 & Accept \\
\hline
\end{tabular}

The results show that the consumer's perception of CSR has a positive effect on the organization's brand image, hence supporting hypothesis 1 . Hypothesis 2 predicted that the perceived CSR is related to trust, and is rejected due to its insignificance. Thus, it can be concluded that in Pakistan, the consumer's perceived CSR has no impact on the level of trust that the consumers have on a particular organization. The dependent variable, trust, has an overall $\mathrm{R}^{2}$ of 0.58 . This means that the variable of trust explains $58 \%$ of the variation in the complete model. Hypothesis 3 is also rejected due to insignificant relationship between perceived CSR and trust. Hence, the consumer's perceived CSR does not have any effect on consumer satisfaction as well. However, the brand image has a positive effect on consumer satisfaction and trust, thus giving support to hypotheses 4 and 5 . Furthermore, it can be seen from Table 5 that all four constructs of perceived CSR, namely, philanthropy, environment, consumers and workers, enjoy a positive, significant relationship with it.

Table 5: Factors Determining Perceived CSR

\begin{tabular}{lcc}
\hline Relationship & Estimate & p-value \\
\hline Philanthropy $\rightarrow$ Perceived CSR & 0.828 & .000 \\
Environment $\rightarrow$ Perceived CSR & 0.691 & .000 \\
Consumers $\rightarrow$ Perceived CSR & 0.662 & .000 \\
Workers $\rightarrow$ Perceived CSR & 0.746 & .000 \\
\hline
\end{tabular}

Table 6 presents the results of the mediation analysis. One of the aims of the research was to examine if the brand image mediates the relationship between CSR, satisfaction and trust. The mediating effects of the brand image on satisfaction and trust, were tested by bootstrapping in Amos 18, and interpreted according to the method described in Zhao, Lynch and Chen (2010). The direct relationship between the consumers' perceived CSR, and 
satisfaction is statistically insignificant, however, the brand image indirectly, or completely mediates the relationship, as the indirect effect is highly significant. This means that the perceived CSR causes variation in brand image, which in turn causes the satisfaction to vary. The same holds true for perceived CSR and trust. There is no significant, direct relationship between the two variables. However, once again, brand image completely mediates the relationship between brand image and consumer's trust. Hence, hypothesis $4 \mathrm{a}$ and $5 \mathrm{a}$ are accepted, as brand image indirectly explains the variation in satisfaction, and trust, due to perceived CSR, and there is no unique, direct relationship between the variables.

Table 6: Mediation Analysis and Hypothesis Testing

\begin{tabular}{ccccccc}
\hline H4a & Relationship & $\begin{array}{c}\text { Direct } \\
\text { Effect }\end{array}$ & P-value & $\begin{array}{c}\text { Indirect } \\
\text { Effect }\end{array}$ & P-value & Decision \\
\hline H5a & $\begin{array}{c}\text { Perceived CSR } \rightarrow \\
\text { Brand Image } \rightarrow \\
\text { Satisfaction } \\
\text { Perceived CSR } \rightarrow \\
\text { Brand Image } \rightarrow \text { Trust }\end{array}$ & 0.167 & .147 & 0.253 & .003 & $\begin{array}{c}\text { Full } \\
\text { mediation } \\
\text { holds } \\
\text { Full } \\
\text { mediation } \\
\text { holds }\end{array}$ \\
\hline
\end{tabular}

\section{Discussion and Conclusions}

This study was conducted to ascertain the positive impact of the consumer's perceptions of CSR on brand image, trust and satisfaction, in the apparel industry of Pakistan. Results reveal that consumers believe that corporations have an obligation towards the society, and their perception of the level of responsibility, assumed by the companies with respect to philanthropy, environment, consumers and workers, has an impact on the ultimate consumer behaviour.

The results of this research accepted hypothesis 1 , which predicted that the perceived CSR is positively related to brand image. This finding is in agreement with the work of He and Lai (2014). Becker-Olsen et al. (2005) noted that the brand image of a company suffers if it gets exposed to negative publicity on its CSR activities. Organizations can use cause-related marketing as a possible marketing strategy to formulate, and reinforce a positive brand image in the minds of consumers (Dacin \& Brown, 2006). This indicates that if an organization concentrates on portraying itself as socially conscious, and communicates the same effectively to its consumers, then its brand image will enhance in the minds of the consumers. CSR 
initiatives can be better designed, and be more visible so that corporations can benefit from favourable consumer responses.

This study, however, rejected hypothesis 2 , which predicted that the perceived CSR has a positive effect on consumer's trust in the brand. This finding is exclusively unique to this study, and does not confirm the results found by Kennedy, Ferrell and LeClair (2001), and Swaen and Chumpitaz (2008). This means that even though a corporation may be perceived as socially responsible, consumers still might not build a relationship of trust with it. This may be the result of the general mind set of the population of Pakistan, where people find it difficult to put their trust in businesses, organizations and even other people, readily and are always looking for any potential ulterior motives behind actions. This means that CSR activities by the organizations will not directly lead to an increased incidence trust in consumers, and CSR initiatives should be designed in a manner that does not focus on securing trust directly and obviously.

This study also found a positive, but insignificant relationship between perceived CSR and consumer's satisfaction. Hence, hypothesis 3 is not supported as well. This finding is also inconsistent with the findings revealed elsewhere (Luo \& Bhattacharya, 2006; Martínez \& del Bosque, 2013), and social marketing, by itself, might not lead to an increase in the consumer satisfaction in Pakistan. Even though CSR initiatives help consumers in other countries differentiate between organizations (Gupta $\&$ Pirsch, 2006), this is not entirely the case in Pakistan. The Pakistani consumer is probably still not aware of the significance of CSR activities, and is therefore not giving it enough importance.

Hypothesis 4, proposing that the brand image impacts satisfaction positively, was accepted. This reinforces the fact that the satisfaction level in Pakistani consumers, is a result of more than one aspect of a company's activities, and consumers look at the whole bundle offered by the organizations, of which perceived CSR has an insignificant role. Moreover, according to hypothesis $4 \mathrm{a}$, the brand's image completely mediates the relationship, and the variations in consumer's satisfaction can be explained by the changes in the brand's image, rather than perceived CSR directly.

The last research hypothesis, $\mathrm{H} 5$, was accepted, which predicted that the brand's image is positively related to consumer's trust. This indicates that consumers in Pakistan come to trust an organization, not just on the basis of perceived CSR activities, but rather on the basis of the complete impression of a brand's total personality. This is further strengthened by the 
acceptance of hypothesis 5a, where the brand image, again, completely explains the variation in trust, due to perceived CSR. Thus, marketers could look at CSR as an important determinant of brand image, but should not rely only on CSR activities to gain the consumer's trust.

This study can help organizations in better understanding the consumers' mind set towards the business' efforts of perceived CSR, so that effective marketing strategies can be formulated. It is noteworthy that only the brand image is positively influenced by CSR activities, and the adoption of CSR practices does not directly translate into an increased level of satisfaction and trust. If the corporations want to enhance these directly, they will have to work strategically and rigorously to create awareness of the importance of CSR initiatives, so that these can be used as a strategic promotional tool, and become a source of competitive advantage for an organization.

This study has been based only on the perceptions of CSR initiatives in the apparel industry of Pakistan, and is further restricted to the city of Lahore. The data has also been collected only from university students. It should also be taken into consideration that for other industries and cities, the findings might or might not be similar. The research is also based on empirical information, and future studies can be made more qualitative in nature. This can be done by conducting focus groups and indepth interviews, so as to glean a better picture of why perceived CSR does not directly impact the desired level of satisfaction and trust in Pakistan. 


\section{References}

Aaker, D. A. (1991), Capitalizing on the Value of a Brand Name, Journal of Business Research, Elsevier, 29(3), 247-248.

Aaker, D. A. (1996). Measuring brand equity across products and markets. California Management Review, 38(3), 103.

Ahmad, S. J. (2006). From principles to practice. Journal of Corporate Citizenship, 2006(24), 115-129.

Arli, D. I. \& Lasmono, H. K (2010). Consumers' Perception of Corporate Social Responsibility in a Developing Country. International Journal of Consumer Studies 34(1), 46-51.

Ballantyne, R., Warren, A., \& Nobbs, K. (2006). The evolution of brand choice. The Journal of Brand Management, 13(4), 339-352.

Bartholomew, D.J., \& Knott, M. (1999). Latent Variable Models and Factor Analysis Kendalls Library of Statistics, No. 7(2nd. ed.). New York, NY: Edward Arnold

Becker-Olsen, K. L., Cudmore, B. A., \& Hill, R. P. (2006). The impact of perceived corporate social responsibility on consumer behavior. Journal of Business Research, 59(1), 46-53.

Blombäck, Anna and Christina Scandelius. 2013. Corporate Heritage in CSR Communication: A Means to Responsible Brand Image? edited by Balmer. Corporate Communications: An International Journal, 18(3):362-82.

Bögel, Paula \& Maria, 2019. Company Reputation and Its Influence on Consumer Trust in Response to Ongoing CSR Communication. Journal of Marketing Communications, 25(2):115-36.

Bollen, K. A. (1989). A new incremental fit index for general structural equation models. Sociological Methods E Research, 17(3), 303-316.

Boshoff, C., \& Gray, B. (2004). The relationships between service quality, customer satisfaction and buying intentions in the private hospital industry. South African Journal of Business Management, 35(4), 27-35. 
Bowen, H. R. (1953). Graduate Education in Economics. The American Economic Review, 43 (4), 1-223.

Byrne, B. M. (2010). Structural equation modeling with AMOS: Basic concepts, applications, and programming (2nd Edition). New York: Routledge.

Carrigan, M. \& Attalla, A. (2001), The Myth of the Ethical Consumer - Do Ethics Matter in Purchase Behavior? Journal of Consumer Marketing 18(7), 560-78.

Carroll, A. B. (1979). A three-dimensional conceptual model of corporate performance. Academy of Management Review, 4(4), 497-505.

Creed, W. D., \& Miles, R. E. (1996), Trust in organizations: a conceptual framework linking organizational forms, managerial philosophies, and the opportunity costs of controls. In R. M. Kramer and T. R. Tyler (Eds.), Trust in Organizations: Frontiers of Theory and Research (pp. 16-38). Thousand Oaks, CA: Sage

Crosby, L. A., Evans, K. R., \& Cowles, D. (1990). Relationship quality in services selling: An interpersonal influence perspective. The Journal of Marketing, 54 (July), 68-81.

Da Giau, A., Macchion, L., Caniato, F., Caridi, M., Danese, P., Rinaldi, R., \& Vinelli, A. (2016). Sustainability Practices and Web-Based Communication: An Analysis of the Italian Fashion Industry. Journal of Fashion Marketing and Management: An International Journal, 20(1), 72-88.

Dacin, P. A., \& Brown, T. J. (2006). Corporate branding, identity, and customer response. Journal of the Academy of Marketing Science, 34(2), 95-98.

Dahlsrud, A. (2006). How corporate social responsibility is defined: An analysis of 37 definitions. Corporate Social Responsibility and Environmental Management, 15(1), 1.

Davis, K. (1960). Can business afford to ignore social responsibilities? California Management Review (Pre-1986), 2(000003), 70. 
Drumwright, M. E. (1994). Socially responsible organizational buying: Environmental concern as a noneconomic buying criterion. The Journal of Marketing, 58 (3), 1-19.

Esch, F., Langner, T., Schmitt, B. H., \& Geus, P. (2006). Are brands forever? how brand knowledge and relationships affect current and future purchases. Journal of Product \& Brand Management, 15(2), 98-105.

Fornell, C. \& Larcker, D. (1981), Evaluating Structural Equation Models with Unobservable Variable and Measurement Error, Journal of Marketing Research, 18, 39-50.

Gupta, S., \& Pirsch, J. (2006). The company-cause-customer fit decision in cause-related marketing. Journal of Consumer Marketing, 23(6), 314-326.

Hair, J. F., Anderson, R.E., Tatham, R.L. \& Black, W.C. (1995), Multivariate Data Analysis. Englewood Cliffs, NJ: Prentice-Hall.

He, H., \& Li, Y. (2011), CSR and Service Brand: The Mediating Effect of Brand Identification and Moderating Effect of Service Quality, Journal of Business Ethics, 100(4), 673-688.

He, Y., \& Lai, K. K. (2014). The effect of corporate social responsibility on brand loyalty: The mediating role of brand image. Total Quality Management E Business Excellence, 25(3-4), 249-263.

Hildebrand, D., Sen, S. \& Bhattacharya, C. (2011). Corporate Social Responsibility: A Corporate Marketing Perspective. European Journal of Marketing, 45(9/10), 1353-1364

Hosmer, L. T. (1994), Strategic Planning as if Ethics Mattered, Strategic Management Journal, 15, 17-34.

Kassinis, G. I. \& Soteriou, A.C. (2015), Environmental and Quality Practices: Using a Video Method to Explore Their Relationship with Customer Satisfaction in the Hotel Industry. Operations Management Research, 8(3-4), 142-56.

Keller, K. L. (1993). Conceptualizing, measuring, and managing customerbased brand equity. The Journal of Marketing, 57 (January), 1-22. 
Kennedy, M. S., Ferrell, L. K., \& LeClair, D. T. (2001). Consumers' trust of salesperson and manufacturer: An empirical study. Journal of Business Research, 51(1), 73-86.

Kerlinger, F. N., \& Lee, H. B. (2000). Foundations of behavioral research: Educational and psychological inquiry. (4th ed.) Holt, Rinehart and Winston New York: Harcourt College Publishers.

Kim, S. 2019. The Process Model of Corporate Social Responsibility (CSR) Communication: CSR Communication and Its Relationship with Consumers' CSR Knowledge, Trust, and Corporate Reputation Perception. Journal of Business Ethics, 154(4), 1143-59.

Kotler, P. (2001). Marketing Management, (10th ed.). Canada: Pearson Education.

Lee, M. P. (2008). A review of the theories of corporate social responsibility: Its evolutionary path and the road ahead. International Journal of Management Reviews, 10(1), 53-73.

Levy, S. J. (1959). Symbols for sale. Harvard Business Review, 37(4), 117-124.

Lion, A., Macchion, L., Danese, P. and Vinelli, A. (2016), "Sustainability approaches within the fashion industry: The supplier perspective", Supply Chain Forum: An International Journal, 17(2), 95-108.

Luo, X., \& Bhattacharya, C. B. (2006). Corporate social responsibility, customer satisfaction, and market value. Journal of Marketing, 70(4), $1-18$.

Maignan, I., \& Ferrell, O. (2004). Corporate social responsibility and marketing: An integrative framework. Journal of the Academy of Marketing Science, 32(1), 3-19.

Martínez, P., \& del Bosque, I. R. (2013). CSR and customer loyalty: The roles of trust, customer identification with the company and satisfaction. International Journal of Hospitality Management, 35 (2013), 89-99.

Ming, T.T., Ismail, H.B. and Rasiah, D. (2011), Hierarchical Chain of Consumer-Based Brand Equity: Review From The Fast Food Industry, International Business \& Economics Research Journal, 10(9), 67-80. 
Mithas, S., Krishnan, M. S., \& Fornell, C. (2005). Why do customer relationship management applications affect customer satisfaction? Journal of Marketing, 69(4), 201-209.

Morgan, R.M., Hunt, S.D., 1994. The commitment-trust theory of relationship marketing. Journal of Marketing, 58, 20-38.

Murphy, P. E. (1978). An evolution: Corporate social responsiveness. University of Michigan Business Review, 6(30), 19-25.

Nunnally, J. C. (1978). Psychometric Theory, McGraw-Hill, New York.

Othman, M. A., \& Hemdi (2013). Corporate social responsibility (CSR) activities, brand image, and hotel guest retention. Hospitality and Tourism: Synergizing Creativity and Innovation in Research, 17 (2013), 153-160.

Park, E, Kim, K.J., \& Kwon, S.J. (2017). Corporate Social Responsibility as a Determinant of Consumer Loyalty: An Examination of Ethical Standard, Satisfaction, and Trust. Journal of Business Research, 76 (July 2017), 8-13.

Plummer, J. T. (1985), Brand Personality: A Strategic Concept for Multinational Advertising, Marketing Educator's Conference, Young E Rubicam, pp. 1-31, New York.

Porter, M. E., \& Kramer, M. R. (2002). The competitive advantage of corporate philanthropy. Harvard Business Review, 80(12), 56-68.

Romaniuk, J., \& Sharp, B. (2003). Measuring brand perceptions: Testing quantity and quality. Journal of Targeting, Measurement and Analysis for Marketing, 11(3), 218-229.

Rouen, T. (2003). Brands and image value: the symbolic dimension of economic activities. Kaleidoscope, 177-191.

Sekaran, U. (2000). Research Methods for Business: A Skill Building Approach (3rd Ed). New York: John Wiley \& Sons

Sen, S., \& Bhattacharya, C. B. (2001). Does doing good always lead to doing better? Consumer reactions to corporate social responsibility. Journal of Marketing Research, 38(2), 225-243. 
Shamma, H. M., \& Hassan, S. S. (2011). Integrating product and corporate brand equity into total brand equity measurement. International Journal of Marketing Studies, 3(1), 11.

Sonodh Jr, S. L., Omar, M. W., Wahid, N. A., Ismail, I., \& Harun, A. (2007). The effect of brand image on overall satisfaction and loyalty intention in the context of color cosmetic. Asian Academy of Management Journal, 12(1), 83-107.

Swaen, V., \& Chumpitaz, R. C. (2008). Impact of corporate social responsibility on consumer trust. Recherche Et Applications En Marketing (English Edition), 23(4), 7-34.

Turban, D. B., \& Greening, D. W. (1997). Corporate social performance and organizational attractiveness to prospective employees. Academy of Management Journal, 40(3), 658-672.

Ueltschy, L. C., Laroche, M., Eggert, A., \& Bindl, U. (2007). Service quality and satisfaction: An international comparison of professional services perceptions. Journal of Services Marketing, 21(6), 410-423.

Walsh, G, \& Bartikowski, B. (2013). Exploring Corporate Ability and Social Responsibility Associations as Antecedents of Customer Satisfaction Cross-Culturally. Journal of Business Research 66(8):989-95.

Zhao, X., Lynch, J. G., \& Chen, Q. (2010). Reconsidering Baron and Kenny: Myths and truths about mediation analysis. Journal of Consumer Research, 37(2), 197-206. 


\section{Questionnaire \\ SECTION A (RESPONDENTS BIODATA)}

Gender

\begin{tabular}{|l|l|}
\hline Male & Female \\
\hline
\end{tabular}

Educational qualification

\begin{tabular}{|l|l|l|l|}
\hline $\begin{array}{l}\text { Masters or } \\
\text { higher }\end{array}$ & Bachelors & $\begin{array}{l}\text { Professional } \\
\text { Qualification }\end{array}$ & Other \\
\hline
\end{tabular}

Marital status

\begin{tabular}{|l|l|}
\hline Single & Married \\
\hline
\end{tabular}




\section{SECTION B (CORPORATE SOCIAL RESPONSIBILITY)}

Please the tick the appropriate responses:

To what extent do you agree with each of the following propositions about this company? I have the impression that this company tries to... (between $1=$ strongly disagree and $5=$ strongly agree)

\begin{tabular}{ccccc}
\hline $\begin{array}{c}\text { strongly } \\
\text { agree }\end{array}$ & agree & neutral & disagree & $\begin{array}{l}\text { strongly } \\
\text { disagree }\end{array}$ \\
\hline
\end{tabular}

Help developing countries

Support social and cultural activities (arts, culture, sports) in the regions where it operates

Develop projects in poor countries

Support humanitarian cause(s)

Reduce its consumption of natural resources

Make its production process more

Environmentally friendly

Make its products as ecological as

possible

Look after consumers' rights (in terms of aftersales service,

guarantees, information)

Treat customers fairly

Provide consumers with accurate information About the products' composition

Treat workers fairly irrespective of gender And ethnic or religious background

Create jobs

Act in accordance with current laws and Legislation

Protect employee rights

Help all employees who so desire to receive Further training

Guarantee employees' health and safety

Respect human rights in all countries where the

Company operates

Not operate in countries where human rights are violated 
To what extent do you agree with each of the following statements about companies' responsibilities? Companies should... (between $1=$ strongly disagree and $5=$ strongly agree)

\begin{tabular}{|c|c|c|c|c|}
\hline & $\begin{array}{c}\begin{array}{c}\text { Strongly agree } \\
\text { agree }\end{array} \\
\end{array}$ & neutral & disagree & $\begin{array}{l}\text { Strongly } \\
\text { disagree }\end{array}$ \\
\hline \multicolumn{5}{|l|}{ Make profits } \\
\hline \multicolumn{5}{|l|}{ Respect human rights } \\
\hline \multicolumn{5}{|l|}{$\begin{array}{l}\text { Make their products as } \\
\text { ecologically as possible }\end{array}$} \\
\hline \multicolumn{5}{|l|}{ Seek economic growth } \\
\hline \multicolumn{5}{|l|}{$\begin{array}{l}\text { Not use environmentally harmful } \\
\text { production Processes }\end{array}$} \\
\hline $\begin{array}{l}\text { Guarantee employees' health and } \\
\text { safety }\end{array}$ & & & & \\
\hline
\end{tabular}

\section{SECTION C (BRAND IMAGE)}

For each of the following statements about the product chosen, which best reflects your opinion? (Between $1=$ strongly disagree and $5=$ strongly agree)

\begin{tabular}{|c|c|c|c|c|c|}
\hline & $\begin{array}{l}\text { Strongly } \\
\text { agree }\end{array}$ & agree & neutral & disagree & $\begin{array}{l}\text { Strongly } \\
\text { disagree }\end{array}$ \\
\hline \multicolumn{6}{|l|}{ Brand $\mathrm{X}$ makes me feel good } \\
\hline \multicolumn{6}{|l|}{ Brand $x$ makes me feel delighted } \\
\hline \multicolumn{6}{|l|}{$\begin{array}{l}\text { Brand } x \text { increases my frequency } \\
\text { of use }\end{array}$} \\
\hline \multicolumn{6}{|l|}{ Brand $x$ gives me pleasure } \\
\hline \multicolumn{6}{|l|}{$\begin{array}{l}\text { Usage of brand } x \text { prevents me } \\
\text { from looking cheap }\end{array}$} \\
\hline \multicolumn{6}{|l|}{$\begin{array}{l}\text { Brand } x \text { enhances the perceptions } \\
\text { that I have a desirable lifestyle }\end{array}$} \\
\hline \multicolumn{6}{|l|}{$\begin{array}{l}\text { Brand } x \text { helps me to better fit into } \\
\text { my social Group }\end{array}$} \\
\hline \multicolumn{6}{|l|}{ brand $x$ helps me feel accepted } \\
\hline \multicolumn{6}{|l|}{$\begin{array}{l}\text { Brand } x \text { improves the way I am } \\
\text { perceived by Others }\end{array}$} \\
\hline \multicolumn{6}{|l|}{ Brand $x$ performs as it promises } \\
\hline \multicolumn{6}{|l|}{$\begin{array}{l}\text { Brand } x \text { can be dependable for } \\
\text { use }\end{array}$} \\
\hline $\begin{array}{l}\text { Brand X makes a good impression } \\
\text { of me on other people }\end{array}$ & & & & & \\
\hline
\end{tabular}




\section{SECTION D (CONSUMER TRUST)}

To what extent do you agree with the following statements about this company? (between 1 = strongly disagree and $5=$ strongly agree)

\begin{tabular}{|c|c|c|c|}
\hline & $\begin{array}{c}\begin{array}{c}\text { strongly agree } \\
\text { agree }\end{array} \\
\end{array}$ & neutral disagree & $\begin{array}{l}\text { strongly } \\
\text { disagree }\end{array}$ \\
\hline \multicolumn{4}{|l|}{$\begin{array}{l}\text { This company's products give me a } \\
\text { sense of security }\end{array}$} \\
\hline \multicolumn{4}{|l|}{$\begin{array}{l}\text { I trust the quality of this company's } \\
\text { products }\end{array}$} \\
\hline \multicolumn{4}{|l|}{$\begin{array}{l}\text { Buying this company's products is a } \\
\text { quality Guarantee }\end{array}$} \\
\hline \multicolumn{4}{|l|}{$\begin{array}{l}\text { This company is interested in its } \\
\text { customers }\end{array}$} \\
\hline \multicolumn{4}{|l|}{$\begin{array}{l}\text { This company is forthright in its dealing } \\
\text { with consumers }\end{array}$} \\
\hline $\begin{array}{l}\text { This company is honest with its } \\
\text { customers }\end{array}$ & & & \\
\hline
\end{tabular}

\section{SECTION E (CONSUMER SATISFACTION)}

To what extent are you satisfied with this product? For each of the following statements about the product chosen, which best reflects your opinion? (Between $1=$ strongly disagree and $5=$ strongly agree)

\begin{tabular}{|c|c|c|c|c|c|}
\hline & $\begin{array}{c}\text { Strongly } \\
\text { agree }\end{array}$ & agree & neutral & disagree & $\begin{array}{l}\text { Strongly } \\
\text { disagree }\end{array}$ \\
\hline \multicolumn{6}{|l|}{$\begin{array}{l}\text { I think that I did the right thing when I } \\
\text { used this brand }\end{array}$} \\
\hline \multicolumn{6}{|l|}{$\begin{array}{l}\text { I believe that using this brand is } \\
\text { usually a very satisfying experience }\end{array}$} \\
\hline \multicolumn{6}{|l|}{$\begin{array}{l}\text { I am very satisfied with my decision to } \\
\text { use this brand }\end{array}$} \\
\hline \multicolumn{6}{|l|}{$\begin{array}{l}\text { My choice to use this brand has been a } \\
\text { wise One }\end{array}$} \\
\hline $\begin{array}{l}\text { This brand does a good job of satisfying } \\
\text { my needs }\end{array}$ & & & & & \\
\hline
\end{tabular}

